\title{
Traditional Classroom VS E-learning in Higher Education: Difference between Students' B ehav- ioral Engagement
}

\author{
http://dx.doi.org/10.3991/ijet.v9i2.3268
}

Fei Li, Jingyao Qi, Guiwei W ang and Xiaofeng Wang

$\mathrm{H}$ arbin Institute of Technology, Harbin, China

\begin{abstract}
We discuss traditional classroom, e-learning, behavioral engagement and difference between behavioral engagements in two kind of instruction environment. Results from variance analyses suggest that there is no significant difference between engagements of active learning in different classroom conditions, and there exist significant differences on higher-level learning of innovative and critical thinking. Our findings highlight students' behavioral engagements in two environments have no significant advantage over each other, but e-learning facilitates higherlevel learning better.
\end{abstract}

Index Terms- behavioral engagement, difference, e-learning, traditional classroom

\section{INTRODUCTION}

We are living in an information technology age and many people, especially students in higher education, depend on computer to do the work. And most of higher educational institutions have aware that using network technology can create, foster, deliver, and facilitate learning, and enhance students experience and knowledge. So the rapid developments and growth of information and communication technology have had a profound influence on higher education. That is called e-learning, which here means that teachers and students perform course task through internet, a way different with traditional classroom.

W ithin the last 20 years, the proponents of learning via computers have challenged the view that the traditional lecture is necessarily the most appropriate means of facilitating learning in a university environment.[1] People found that e-learning has its own advantages on student learning outcomes through researches on comparison research about differences between e-learning and traditional classroom. A research by Thomas et al. compared students' outcomes of classroom-based and internet-based course of construction safety. Results found that performance across four examinations of students on internetbased course, at specific reference to application-type examination items, may be significantly higher than performance of students on class-based course. [2] Chen et al. studied the effectiveness and student perceptions in a MBA Accounting Course in two different environments: blended-learning and traditional classroom, and found that there were tradeoffs in the processes for the two delivery methods examined. That is, the traditional classrooms will continue to offer benefits that arguably cannot fully be obtained in any other manner. But gaps in process effec- tiveness will continue to be narrowed as technology becomes friendlier for both instructor and students. [3] Some scholars present that the results of a study to evaluate the effect of using electronic learning versus lecture of students at a large state faculty where experien- ce with and access to computer facilities are limited with respect to learning outcomes, including knowledge gained, practice, attitudes and opinions toward traditional lectures and elearning. [4] While there is more discussion about learning outcome comparison of e-learning and traditional learning environment. B ut there is rarely literature to research why the differences emerges.

We presume that the engagement difference in traditional classroom-based and internet-based course leads to different learning outcome. And so following discussion mainly focuses on behavior engagement. We will suggest the proposition that there is difference between students' behavior engagements in two different course environments.

The rest of the paper is organized as follows. In the next section, we define the behavior engagement, which shows the framework of comparing two instruction method of elearning and face to face. Subsequent sections consecutively describe the construction operationalization and data collection method, present the data analysis procedure and the results of the differences testing. The paper concludes with a discussion about our findings and direction for the future research.

\section{RESEARCH FRAMEWORK}

In essence, education means to establish a defined communication between teachers and learners aiming generally to realize the promotion of knowledge, increase of information, acquisition of skill, and to make a change in learner's capabilities. And from this point of view, education can be reckoned a type of communications or relation furthermore, and can be seen as an issue blended in communications, and any event or change in communications, communication vehicles and communications techniques directly influence education. [5] Here, education could be divided into traditional classroom and e-learning.

\section{A. Traditonal Classroom and E-learning}

A traditional classroom refer to rooms consist of clean pastel-colored walls and rows of desks and chairs facing a lectern were placed under the microscope.[6] For ages, education has been centered on attending classes day after day, and people found that school facilities could affect learning. In a traditional classroom, education is mainly 
based on teaching system and often focuses on the material itself rather than the learners and differences between capabilities and learning skills. [7] At the same time, learners are naturally obliged to harmonize their own techniques and learn ability. Traditional classroom does not stimulate the senses or the mind, and on the contrary inspires rote learning.

The term e-learning widely refers to any electronically assisted instruction, and is often associated with instruction offered via computer and the internet. By using various electronic delivery methods, learning can be facilitated in aspect of the transmission of information and interaction. So e-learning has its own special characteristics, including advantages and disadvantages compared with traditional classroom. [8] While with the trend of teaching in university to becoming more learner-centered developing, electronic delivery has been popularized as an alternative or an adjunct to traditional lectures. [9] A nd the learner-centered instruction means that students will engage more in classroom. So it can be understood that one of the primary aims of higher education in today's information technology enabled classroom, is to make students more active in the learning process. [10]

\section{B. Behavioral Engagement}

Engagement has been identified in the learning literature as a research priority [11]. B ehavioral engagement is an important aspect, which is most commonly defined in three ways of positive conduct, involvement in learning and academic tasks, and participation in school-related activities [12] Here, behavioral engagement denotes observable behaviors during the course, such as attention, asking questions, contributing to class discussion.

Generally, engagement is determined by the interactions between the environment and the individuals, so that social and academic changes in class modify students' perceptions and engagement. [13] That is, engagement mediates the influence of curricular and instructional changes on student performance and achievements. [14]

\section{Difference between B ehavioral Engagements in Tra- ditional Classroom and E-Learning}

The transformation from traditional classroom to elearning means the change of learning environment.

Traditional classroom can be classified in two kinds of teacher-centered and learner-centered classroom. Teachercentered traditional classroom in university aims at imparting knowledge to students, in which teacher performs main role, and students often focus on something what the teacher is saying, write down information what they are receiving, think something independently what they are listening. So their learning mainly behaves passive behaviors. With teaching idea changing, the traditional instructions are transforming from teacher--centered classroom to learner-centered one. A nd learner--centered traditional classrooms pay more attention to learning ability, where besides listening, writing and thinking, students need participate truly in courses. They have more opportunities to answer questions, ask questions, co-operate with classmates to complete some tasks or give a prepared speech on a certain topic. Those learning behaviors are active and cooperative learning behaviors, and proved to be more effective for students' learning outcomes.
The aims of all instructions are to lead the learners to take on their own responsibility for learning, by acquiring the tools and skills for doing so, and technology permitted this learning to take place virtually.[10] E-learning, as a teaching method, coincides with an increasing proportion of non-traditional students in higher education as a result of policies which seek to widen participation.[15] Although people found that the distance or electronic format pose challenges particularly in those aspects of learning that require more higher-level learning.[16] Some research suggested that computer did facilitate lower levels of learning, such as rote memorization of facts, and higherlevel learning skills was more problematic in an entirely online environment, notwithstanding the advances in technologies.[17]

So the engagement in different learning environment has its own characteristics, which mainly behaves that students engagement in e-learning is more active (see TABLE I). A nd we propose the hypothesis 1: behavioral engagement in e-learning is more active than that in traditional classroom.

TABLE I. BEHAVIORAL ENGAGEMENT

\begin{tabular}{|c|c|l|c|}
\hline \multirow{2}{*}{ Item } & \multicolumn{3}{|c|}{ Comparison } \\
\cline { 2 - 4 } & \multicolumn{2}{|c|}{ Traditional Classroom } & E-L earning \\
\hline \multirow{3}{*}{ Characters } & Teacher-Centered & L earner-Centered & L earner-Centered \\
\cline { 2 - 4 } & Passive learning & active learning & $\begin{array}{c}\text { M ore A ctive } \\
\text { L earning }\end{array}$ \\
\hline
\end{tabular}

\section{III.METHODOLOGY}

\section{A. Measurement}

A comparison study was designed to test the differences. We used mainly the survey method to gather the data for the study. A ccording to discussion above, NSSE questionnaire and NSSE-CHINA questionnaire, a simple survey instrument was developed. The questionnaire includes the attitude or intention toward some questions about behavioral engagement in classroom, including to listen to what teachers say, to write down something important, to work with other students on task during class, to think or respond to questions without fixed answer in classroom, to make a class presentation, to ask question in class or contribute to class discussion, to challenge teachers' opinion. And the questions were answered using a 4-point Likert scales, ranging from 1 which means strongly disagree to 4 which means strongly agree.

\section{B. Participants}

In the research, we chose undergraduates of two classes at the same grade, who behaved similar at normal classroom. Giving the same learning content, class 1 has 29 students, who participated in traditional classroom as comparison group, and class 2 has 30, who participated in e-learning, as intervention group. A fter respectively attending class, we conducted survey to understand learner attitudes or intentions toward engagement in traditional classroom and e-learning.

\section{Data Analysis}

All analyses were performed using SPSS19.0 statistical software package. 
Data were summarized as the mean and standard deviation for continuous variables of different group, and T-test was used to distinguish differences for those.

To understand if underlying dimension of active behavior engagement in classroom was logical, reliability test was performed by Cronbach's alpha, and construct validity test by $\mathrm{K}$ aiser-M eyer-O klin (KM O) and factor analysis. And the variance analysis was used to analyze two group differences on active and behavioral engagement. $P$-values $<0.05$ were regarded as the significance level.

\section{IV.RESULTS}

\section{A. Descriptive Statistics}

TABLE II summarizes the means, standard deviations of the items for two groups. On the first item, the means are almost equal. On the second item, the mean item of traditional classroom is more than that of e--learning. And on the other items, the means of traditional classroom are all less than correspondent those of e--learning. TABLE III shows significant differences between variables of traditional class room and e--learning,. The results shows that on the two variable of "to think or respond to questions without fixed answer in classroom" and "to challenge teachers' opinion", there exist significant differences between means. According to TABLE II, the two variables' mean of e-learning are both significantly higher than those of traditional classroom.

\section{B. M easurement Rationality}

W e note that the reliability of behavioral engagement is 0.6602 and above 0.6 , indicating that the measurement is reliable. The KMO value is 0.538 and above 0.5 , showing that factor analysis can be used to reduce data.

A nd under extracting one factor, its initial eigenvalue is 2.399, and latent construct can account for 34.265 percent of the variance in the items. The reliability and validity of the measurement are all logic. W e can acquire the data of the latent variable-behavioral engagement by factor analysis to test the hypothesis.

\section{Hypothesisi Testing}

TABLE IV presents the results obtained from the variance analysis.The sig. values of 0.258 and 0.477 indicate that there is no significant difference between students' behavioral engagements in traditional classroom and elearning, failing to confirm the hypothesis.

\section{DISCUSSION}

Our interest in investigating the difference between students' behavioral engagements in traditional classroom and e-learning was triggered by two facets that there exist differences between learning outcomes of two kinds of lectures, and behavioral engagement in learning is demonstrated an effective predictor [18]. So we wonder if there exists difference between behavioral engagements in different course environments.

By elaborating basic concepts and characters and data analysis, we offer some results. We find that there is no significant difference between students' engagements in traditional classroom and e-learning. The result suggests that the simple change in learning environment has no significant effect on students' engagement in instruction. A ccording to $\mathrm{M}$ iserandino, engagement in classroom is
TABLE II. DESCRIPTIVE STATISTICS OF BEHAVIORAL ENGAGEMENT IN TRADITIONAL CLASSROOM AND E-LEARNING

\begin{tabular}{|l|c|c|c|c|}
\hline \multirow{2}{*}{\multicolumn{1}{|c|}{ Items }} & \multicolumn{2}{|c|}{$\begin{array}{c}\text { Traditional } \\
\text { Classroom }\end{array}$} & \multicolumn{2}{l}{ E --L earning } \\
\cline { 2 - 5 } & M & SD & M & SD \\
\hline To listen to what teachers say & 2.21 & .774 & 2.20 & .664 \\
\hline To write down sth. important & 2.41 & .780 & 2.31 & .850 \\
\hline $\begin{array}{l}\text { To work with other students on task } \\
\text { during class }\end{array}$ & 2.24 & .912 & 2.43 & .626 \\
\hline $\begin{array}{l}\text { To think or respond to questions without } \\
\text { fixed answer in classroom }\end{array}$ & 2.52 & .871 & 2.80 & .610 \\
\hline To make a class presentation & 3.00 & .655 & 3.20 & .714 \\
\hline $\begin{array}{l}\text { To ask question in class or contribute to } \\
\text { class discussion }\end{array}$ & 3.03 & .823 & 3.17 & .531 \\
\hline To challenge teachers' opinion & 2.83 & .805 & 2.97 & .102 \\
\hline
\end{tabular}

TABLE III. SIGNIFICANT DIFFERENCES BETWEEN VARIABLES OF TRADITIONAL CLASSROOM AND E-LEARNING

\begin{tabular}{|c|c|c|c|}
\hline \multirow[t]{2}{*}{ Items } & \multirow{2}{*}{$\begin{array}{l}\text { Hy- } \\
\text { poth- } \\
\text { eses }\end{array}$} & $\begin{array}{l}\text { Levene's Test } \\
\text { for Equality } \\
\text { of Variances }\end{array}$ & $\begin{array}{l}\text { t-test for } \\
\text { Equality of } \\
\text { M eans }\end{array}$ \\
\hline & & SIG. & SIG. \\
\hline \multirow{2}{*}{ To listen to what teacher say } & $\mathrm{H}_{\mathbf{0}}$ & .453 & .971 \\
\hline & $\mathrm{H}_{1}$ & & .971 \\
\hline \multirow{2}{*}{ To write down sth. important } & $\mathrm{H}_{0}$ & .684 & .631 \\
\hline & $\mathrm{H}_{1}$ & & .631 \\
\hline \multirow{2}{*}{$\begin{array}{l}\text { To work with other students on task } \\
\text { during class }\end{array}$} & $\mathrm{H}_{0}$ & .131 & .349 \\
\hline & $\mathrm{H}_{1}$ & & .352 \\
\hline \multirow{2}{*}{$\begin{array}{l}\text { To think or respond to questions } \\
\text { without certain answer in classroom }\end{array}$} & $\mathbf{H}_{0}$ & $.016 *$ & .153 \\
\hline & $\mathrm{H}_{1}$ & & .156 \\
\hline \multirow{2}{*}{ To make a class presentation } & $\mathrm{H}_{0}$ & .145 & .267 \\
\hline & $\mathrm{H}_{1}$ & & .267 \\
\hline \multirow{2}{*}{$\begin{array}{l}\text { To ask question in class or contrib- } \\
\text { ute to class discussion }\end{array}$} & $\mathbf{H}_{0}$ & .276 & .465 \\
\hline & $\mathrm{H}_{1}$ & & .469 \\
\hline \multirow{2}{*}{ To challenge teachers' opinion } & $\mathbf{H}_{0}$ & $.000 *$ & .384 \\
\hline & $\mathrm{H}_{1}$ & & .392 \\
\hline
\end{tabular}

Note: $\mathbf{H}_{\mathbf{0}}$ denotes "Equal variances assumed", and $\mathbf{H}_{\mathbf{1}}$ denotes "Equal variances not assumed"; $* P<0.05$

TABLE IV. SIGNIFICANT DIFFERENCES BETWEEN BEHAVIORAL ENGAGEMENT OF TRADITIONAL CLASSROOM AND E-LEARNING

\begin{tabular}{|c|c|c|c|}
\hline Variables & Hypotheses & $\begin{array}{c}\text { Levene's T est for } \\
\text { E quality of Variances } \\
\text { SIG. }\end{array}$ & $\begin{array}{l}\text { t-test for E quality } \\
\text { of M eans } \\
\text { SIG. }\end{array}$ \\
\hline \multirow{2}{*}{$\begin{array}{l}\text { B ehavioral } \\
\text { Engagement }\end{array}$} & $\mathrm{H}_{0}$ & .258 & .476 \\
\hline & $\mathrm{H}_{1}$ & & .477 \\
\hline
\end{tabular}

Note: $\mathbf{H}_{0}$ denotes "Equal variances assumed", and $\mathbf{H}_{\mathbf{1}}$ denotes "Equal variances not assumed"; $* P<0.05$

the outcome of learning motivation [19]. So the result also indicates that little significant effect is exerted by instruction environment change on students learning motivation. From active learning behavior, Students' engagement in elearning has no remarkable advantages on that in traditional classroom.

Our analytical distinction between engagements in items shows that students will engage differently in thinking or responding to questions without fixed answer in classroom, and challenging teachers' opinion. Therein, the first item indicates a certain innovative thinking, and the second item shows critical thinking, both of them are all high-level learning behaviors. So we consider that students in e-learning course have more intention to engage 
in high-level than those in traditional classroom. We interviewed some students of class 2 online, who have more intention toward innovative or critical thinking. They said when teacher's out of sight they have more faith in themselves and would like to trial and error. Their ideas are coordinate with the finding that the virtual learning environment can foster confidence and hence retention to programmes. [20] On the contrary to high-level learning being problematic in e-learning [17]. The results indicate that e-learning facilitate higher-level learning.

W hile we believe we obtained some interesting findings. We also enumerate some limitations and unanswered questions. First, the measurement's reliability and construct validity are just right acceptable. We consider that may be caused by fewer items, extending items will be carried out. Second, the intervention is limited with only one time, data from tracking two classes over the long haul will have better illustration.

\section{VI.CONCLUSION}

Drawing broadly on traditional classroom, e-learning and behavioral engagements in two kind of instruction environment, we suggest there is difference between engagements in different classroom conditions. A nalysis based on 59 students of 2 classes from one university in China denotes that there is no significant difference between students' behavioral engagement in traditional classroom and e-learning. But e-learning facilitate higherlevel learning better at aspects of innovative thinking and critical thinking.

\section{ACKNOWLEDGMENT}

Sponsored by Teaching and Learning Research Program of HIT ([2010]548-098)

\section{REFERENCES}

[1] M agda A bdelaziz DNSa, Salwa Samer K amel DNS, Omar Karam DNSb, A smaa A bdelrah- man DNS. Evaluation of E-Learning Program V ersus Traditonal Lecture Instruction for Undergraduate Nursing Students in a Faculty of Nursing. Teaching and Learning in Nursing, 2011,6, pp.50-58 http://dx.doi.org/10.1016/ j.teln.2010.10.003

[2] H. F. Thomas, R.J. Simmons, G. Jin, A.A. Almeda, and A.A. $M$ annos. Comparison of Student Outcomes for a Classroom-based vs. an Internet-based Construction Safety Course. The Journal of SH\&E Research, 2005, 2(1) , pp.1-15

[3] Clement $C$. Chen, $K$ eith T. Jones. I. A ssessing Effectiveness and Student Perceptions in an M BA A ccounting Course. The Journal of Education Online, 2007,4(1) , pp. 1-5

[4] Magda A bdelaziz DNS, Salwa Samer Kamel DNS, Omar K aram DNS,A smaa A bdelrahman DNS. Evalueation of E-L earning Program Versus Traditional Lecture Instruction for Undergraduate Nursing Students in a Faculty of Nursing. Teaching and Learning in Nursing.2011,(6) , pp.50-58 http://dx.doi.org/10.1016/ j.teln.2010.10.003

[5] M aryam Fooladvand, M ohammad Hossein $Y$ armohammadian. A comparative study between virtual and traditional approaches inhigher education in Iran. Social and Behavioral Sciences. 2011,28, pp. 646-650

[6] Prasanna Ramakrisnan, Y uraidza bt $Y$ ahya, Mohd Nor Hajar Hasrol, A zlan A bdul Aziz. Blended Learning: A Suitable Framework For E-L earning In Higher Education. Social and B ehavioral Sciences, 2012, 67, pp.513-526

[7] Chen Kinshuk, W... Cyber Schooling Framework: Improving M obility and Situated Learning. Proceedings-5th International Conference an advanced Learning technologies. (Taiwan. 2005, July $5-8, p p .290-292$
[8] Baeten, Kyndt, Struyven, \& Dochy. U sing student-centred learning environments to stimulate deep approaches to learning: factors encouraging or discouraging their effectiveness. Educational Research Review, 2010, 5 (3), pp.243-260 http://dx.doi.org/10.1016/ j.edurev.2010.06.001

[9] Stephenson, J., Brown, C., \& Griffin, D.. Electronic delivery of lectures in the university environment: An empirical comparison of three delivery styles. Computational and Eduational, 2008, 50(3) , pp. 640-651.

[10] Raafat George Saadé, Danielle Morin, Jennifer D.E. Thomas. Critical thinking in $\mathrm{E}$-learning environments. Computers in $\mathrm{Hu}$ -

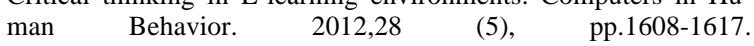
http://dx.doi.org/10.1016/j.chb.2012.03.025

[11] Lorena Blasco-A rcas, Isabel Buil, Blanca Hernández-Ortega, F. J avier Sese. Using clickers in class. The role of interactivity, active collaborative learning and engagement in learning performance. Computers \& Education. 2013,62, pp.102-110 http://dx.doi.org/10.1016/j.compedu.2012.10.019

[12] Jennifer A. Fredricks,Phyllis C. Blumenfeld, ,A lison H. Paris. School Engagement: Potential of the Concept, State of the Evidence. Review of Educational Research. 2004, 74(1) , pp. 59-109 http://dx. doi.org/10.3102/00346543074001059

[13] Finn, J. D., \& Rock, D. A .. A cademic success among students at risk for school failure. Journal of A pplied Psychology, 1997,82, pp.221-234. http://dx.doi.org/10.1037/0021-9010.82.2.221

[14] Guthrie, J. T., \& Wigfield, A.. Engagement and motivation in reading. In M. Kamil, \& P. M osenthal (Eds.). Handbook of reading research, Mahwah, $\mathrm{NJ}$ :Lawrence Erlbaum. 2000, vol. 3, pp. 403-422

[15] Laing, C., Robinson, A... The withdrawal of NTS: an explanatory model. J ournal of Further and Higher Education 2003, 27(2) , pp. 175-185 http://dx.doi.org/10.1080/0309877032000065190

[16] Saadé, R., \& Bahli, B. (2005). The impact of cognitive absorption on perceived usefulness and perceived ease of use in on-line learning: An extension of the technology acceptance model. Information and Management, 42, pp. 317-327. http://dx.doi.org/10.1016/j.im.2003.12.013

[17] Saadé, R., \& Kira, D.. Computer anxiety in E-learning: The effect of computer self-efficacy. Journal of Information Technology in Education,2009, 8, pp. 177-191.

[18] Eleftheria N. Gonida, Katerina V oulala, Grigoris Kiosseoglou. Students' achievement goal orientations and their behavioral and emotional engagement: Co-examining the role of perceived school goal structures and parent goals during adolescence.Learning and Individual Differences. 2009,19, pp. 53-60 http://dx.doi.org/10.1016/j.lindif.2008.04.002

[19] Miserandino, M. (1996). Children who do well in school: Individual differences in perceived competence and autonomy in aboveaverage children. Journal of Educational Psychology, 88(2), pp. 203-214. http://dx.doi.org/10.1037/0022-0663.88.2.203

[20] Heaton-Shrestha, C., M ay, S., Burke. Student retention in higher education: what role for virtual learning environments? Journal of Further and Higher Education. 2009, 33(1) , pp. 83-92. http://dx.doi.org/10.1080/03098770802645189

\section{AUTHORS}

Fei $\mathbf{L} \mathbf{i}$ is with Higher Education Research Institute, Harbin Institute of Technology, Harbin, CHINA (e-mail: thanksall @ hit.edu.cn).

J ingyao Qi is with Higher Education Research Institute, and Undergraduate College, Harbin Institute of Technology, Harbin, CHINA (e-mail: jyq @ hit.edu.cn).

G uiwei W ang is with Undergraduate College, Harbin Institute of Technology, Harbin, CHINA (e-mail: thanksall @ hit.edu.cn).

Xiaofeng $\mathbf{W}$ ang is with Higher Education Research Institute, Harbin Institute of Technology, Harbin, CHINA (e-mail: wxf @ hit.edu.cn).

Submitted 28 A ugust 2013. Published as re-submitted by the authors 20 M arch 2014. 